\title{
Goldberg, Edward.
}

Jews and Magic in Medici Florence: The Secret World of Benedetto Blanis.

Toronto: University of Toronto Press, 2011. Pp. xiv, 331. ISBN 978-1-44251333-1 (paperback) \$32.95.

The materials available for the historical reconstitution of lives and mentalities in the Jewish communities of early modern Europe are sparse in the extreme. Living under the hostile gaze of church authorities, these communities' habitual responses to historical change took the form (as Gershom Scholem observed many decades ago) of Midrashic developments from existing texts and commentaries. They thus tended neither to produce chroniclers nor to preserve writings of any kind once they had passed out of use (except in genizot, repositories for discarded texts or fragments containing the name of God that have sometimes, as in the famous Cairo genizah, proved to be precious resources).

Edward Goldberg's fascinating and compulsively readable study of Benedetto Blanis, a learned Florentine Jew whose birth date falls midway between those of Shakespeare and Descartes, is all the more remarkable for the vividness with which he is able to reconstitute the life and thought of this ambitious and troubled man. Together with its companion text, a superbly edited volume of The Letters of Benedetto Blanis Hebraeo to Don Giovanni dei Medici 
1615-1621, the present study arises out of Goldberg's decades of research in the Archivio di Stato di Firenze and other archives and collections.

The patron to whom Blanis addressed the treasure-trove of more than 200 letters that Goldberg discovered, and whom Blanis saw as offering him a ticket out of the economic and social marginality of the Florentine ghetto and into employment of various kinds in the Medici court, was himself a somewhat marginal figure. Don Giovanni dei Medici, a legitimized son of Cosimo I, the first Grand Duke of Tuscany, and his mistress Eleonora degli Albizzi, was of the princely family, but of course stood outside any main line of inheritance.

In 1587, at the age of twenty, Don Giovanni began a military career that would involve service in the armies of Spain, France, the Holy Roman Empire, and Venice, as well as diplomatic service on behalf of Florence. Military engineer, general, architect, musician, art collector, and voracious reader, Don Giovanni had, in addition, a passionate interest in alchemy and occultismand it was for this reason that he extended his patronage to Blanis, as someone from whom he could learn Hebrew, cabbalistic secrets encoded in the "Sacred Scripture," and other esoteric arts as well.

The appeal of occultism to members of the aristocratic elite was as much political as spiritual. A century earlier, the Benedictine abbot and magus Johannes Trithemius had evoked keen interest from the Margrave of Brandenburg, the Elector Palatine, and the Emperor Maximilian through his claims that the arts he could impart-including ciphering and its occult form, steganographia, as well as natural and spiritual magic-would be of high value in statecraft. During the second half of the sixteenth century, figures including Philipp Melanchthon and André Thevet felt it necessary to refute claims that the occult knowledge of Henricus Cornelius Agrippa had contributed to the military victories of the Emperor Charles V. And as Ioan Couliano has observed, some aspects of Giordano Bruno's magic invite comparison with the more socially manipulative features of the contemporary social sciences.

Don Giovanni dei Medici may have hoped for material as well as spiritual benefits not just from the alchemical laboratory he maintained, but also from the "curious and prohibited books" he gained access to through the young Jewish tradesman and scholar to whom he was offering advancement (Blanis was in his mid-thirties at the time of their first contact).

A Jew invited, as Blanis was, to give instruction in Hebrew to young members of a princely family faced a number of potential problems, of which 
the likelihood of non-remuneration for his services was by far the least. The normal dangers posed by the jealousies, intrigue, and back-biting of court life were exacerbated for Blanis by hostile surveillance from ecclesiastics on the watch for signs of religious contamination, and still further heightened by the fact that members of the court asked him to traffic in occult texts regarded with dark suspicion by the Inquisition.

Additional complications were provided by the fact that Don Giovanni, who had been in the service of the Venetian republic since 1610, established his household in a Venetian palazzo in 1615-and that household included a mistress, Livia Vernazza, aged nineteen when Don Giovanni met her in 1609, but as Goldberg writes, "already burdened with a husband and a history of public prostitution in Lucca and Florence." His marriage with her in 1619, over the vehement objections of the Medici court, resulted after his death in 1621 in a dénouement loosely parallel to what unfolds in the last act of John Webster's near-contemporaneous tragedy The White Devil.

Blanis, who at the time was already imprisoned by the Inquisition on a separate accusation of having attempted the reconversion of Jewish conversos, was scripted by the Medici-Inquisitorial clean-up operation following Don Giovanni's death into the role of a corrupting influence. The fact that he managed by 1623 to secure his own release from prison, and the "favour" of exile from Florence, testifies to a most unusual courage and resilience: under repeated torture, he had refused to make any confession of guilt.

Benedetto Blanis died in 1647, aged nearly 70 . The career of this extraordinary man, brilliantly reconstituted by Edward Goldberg, makes compelling reading.

MICHAEL KEEFER

Professor Emeritus, University of Guelph 